\title{
Ecological intensification in multi-trophic aquaculture ponds: an experimental approach
}

\author{
Christophe Jaeger ${ }^{*}$ and Joël Aubin \\ Institut National de la Recherche Agronomique, Rennes Cedex, France
}

Received 27 March 2018 / Accepted 5 September 2018

Handling Editor: Pauline Kamermans

\begin{abstract}
As aquaculture production is increasing considerably, it needs to become more environmentfriendly. Based on a participatory process, an ecologically intensive pond system was designed to test three hypotheses: a combination of intensive and extensive areas provides more ecosystem services than an intensive or extensive area alone; coupling a planted lagoon with an intensive pond decreases the latter's environmental impacts and maintains or increases its fish productivity; and using formulated feed in polyculture increases growth of all fish species. To test these hypotheses, we designed a specific integrated multi-trophic aquaculture system composed of a polyculture of common carp (Cyprinus carpio), roach (Rutilus rutilus) and tench (Tinca tinca) and a lagoon planted with macrophytes to filter the water. This pond system was compared with "extensive" (unfed) and "semi-intensive" fishpond systems without a planted lagoon. We measured fish growth performances, water quality, chlorophyll concentrations and water and sediment nutrient contents. We also calculated the mass balance of nutrients. Concentrations of total nitrogen and phosphorus increased in sediments, indicating that nutrients were stored in the ponds, especially in planted lagoon; the planted lagoon decreased phytoplankton development, and limited blooms, but it slightly decreased fish growth performances compared to those in semi-intensive fishponds. The formulated feed supplied clearly increased fish growth performances and the survival rate, and seemed also to increase the use of available nutrients in ponds, which improved the production of overall fish biomass. In conclusion, the planted lagoon provides ecosystem services on nutrients cycling and habitat for natural biodiversity. Improving knowledge about nutrient cycles from formulated feed within the pond food web would be useful to increase the amounts of nutrients converted into fish biomass.
\end{abstract}

Keywords: IMTA / fishponds / planted lagoon / common carp / nitrogen / phosphorus

\section{Introduction}

Aquaculture depends on limited resources such as water, fishmeal and fish oil. It also raises sensitive environmental issues that must be considered, such as waste management (Blancheton et al., 2009), the release of reared animals into natural ecosystems (Fontaine et al., 2009) and the use of veterinary medicines in open water systems (Turcios and Papenbrock, 2014). Achieving sustainable aquaculture requires redesigning aquaculture systems with multiple goals: (i) environment-friendly, (ii) producing one or more species for economic markets, (iii) based on local and natural resources, (iv) robust and resilient and (v) having natural and cultural value (especially by supporting biodiversity) (Aubin et al., 2014). In France, the number of freshwater ponds used for fish production is decreasing, whereas the number of ponds for

\footnotetext{
*Corresponding author: christophe.jaeger@inra.fr
}

recreational activities (hunting, angling) is increasing. In some cases, ponds are simply abandoned or dry up, resulting in a loss of biodiversity and landscape modification. However, ponds represent a huge potential for fish production in France (Downing et al., 2006). Restoring this productive activity according to the previously mentioned criteria requires considering several similar principles, one of which is ecological intensification. Ecological intensification is defined as using ecological mechanisms to increase a system's efficiency and production, and to enlarge its role in its region (e.g. environmental aspects, biodiversity, human interests). Integrated multi-trophic aquaculture (IMTA) is a concept developed within the context of ecological intensification. It is based on the principle that rearing extractive organisms (i.e. which extract their nourishment from the environment) counteracts environmental effects of heterotrophic fed fish and restores water quality (Neori et al., 2004). Thus, IMTA increases the efficiency with which nutrients are converted 


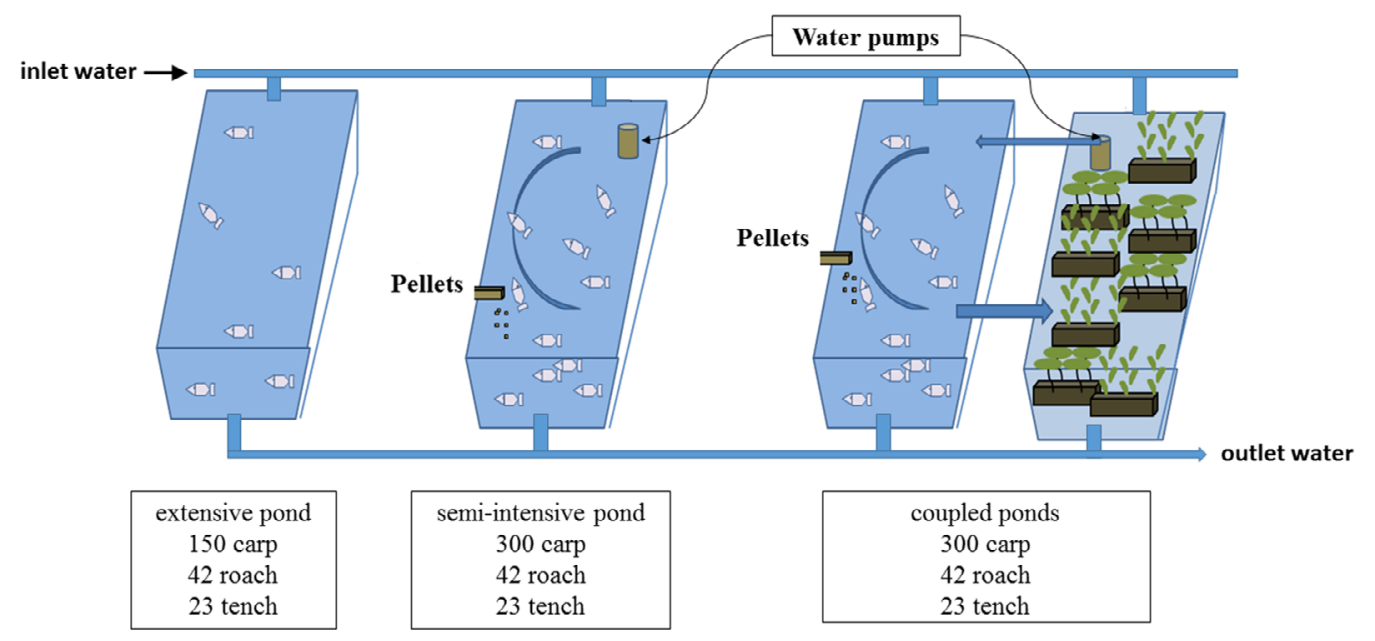

Fig. 1. Diagram of the experimental design.

into total biomass in the system (Crab et al., 2007). IMTA in ponds includes a suspended-growth system (i.e. phytoplankton, zooplankton, bacteria), which provides ecosystem services such as waste assimilation, nutrient recycling and internal food production (Hargreaves, 2006). Consequently, fishpond management, especially polyculture, must be considered in the design of an IMTA fishpond. Milstein (1992) defined a polyculture system as the rearing of several fish species in the same pond that feed on different natural resources. For instance, the burrowing behavior of common carp (Cyprinus carpio) is known to re-suspend nutrients from sediments into the water column, making them available directly to phytoplankton and thus indirectly to other associated fish species that feed on zooplankton, insects, etc. (Ritvo et al., 2004; Rahman et al., 2008). Macrophytes also improve water quality in IMTA systems. Advantages of using wetlands to remove nitrogen $(\mathrm{N})$ from aquaculture water are well demonstrated (Brune et al., 2003; Vymazal, 2007; Gal et al., 2009). Aubin et al. (2014) designed an ecologically intensive pond system to test three hypotheses: (i) a combination of intensive and extensive areas provides more ecosystem services (regulation, biodiversity support and provision services) than an intensive or extensive area alone, (ii) coupling a planted lagoon with an intensive pond decreases the latter's environmental impacts and maintains or increases its fish productivity and (iii) using formulated feed in polyculture benefits all fish species. We performed an experiment to test these hypotheses. Except for its inclusion of macrophytes, the IMTA system developed was similar to the combined aquaculture-algae system of Gal et al. (2007) or the combined intensive-extensive system of Gal et al. (2013). This semi-intensive fishpond-macrophyte system was compared to two fishpond systems without plants in which fish were either supplied with formulated feed or not. The principal aim was to assess the influence of a planted lagoon on water quality in a freshwater pond system at different moments during the production cycle, in which fish were supplied with formulated feed (filtration service). The objective of the study was to explore potential biophysical performances after ecological intensification of ponds with a small set of metrics.

\section{Materials and methods}

\subsection{Ponds}

The experiment was performed from March to November 2014 in the pond facilities of the Aquatic Ecology and Ecotoxicology Experimental Unit of French National Institute for Agriculture (INRA, U3E, Rennes, France, $\left.48^{\circ} 07^{\prime} 13^{\prime \prime} \mathrm{N}, 1^{\circ} 47^{\prime} 33^{\prime \prime} \mathrm{W}\right)$. Eight $500 \mathrm{~m}^{2}(20 \mathrm{~m} \times 25 \mathrm{~m})$ ponds $1 \mathrm{~m}$ deep with bottoms composed of a mix of clay and sediment were used to carry out the experiment. One month before introducing fish, ponds were filled with water from the river running along the site. Water was regularly added during the experiment to compensate for evaporation and seepage. The deepest end of each pond was equipped with an overfill pipe connected to a monk outlet, which is a ponddraining structure at which fish can be caught as the pond drains. At the end of the experiment, the overfill pipe was removed to drain the ponds, and the fish were harvested at the monk outlet.

\subsection{Experimental design}

The experimental design consisted of three treatments, with two replicates of each (Fig. 1). The number of replicates was limited by the number of available ponds of the same size. The first treatment ("extensive") had carp density half that of the other treatments and no formulated feeding. The watershed provided nutrients via river water at filling and when compensating evaporation and seepage. In the second treatment ("semi-intensive"), fish were fed commercial pellets (Tab. 1), and a water pump reproduced the water movement present in the third treatment. The third treatment ("coupled") consisted of two ponds: one used to rear fish, with a fish density and feeding rate identical to those in the semi-intensive pond, and the other used as a planted lagoon. A water pump in the lagoon circulated water from the lagoon to the fishpond. Water returned by gravity to the lagoon through a second pipe whose opening was covered with a net with a mesh size that excluded fishpond fish from the lagoon but allowed the smallest fry to pass through. Each 
lagoon was planted with indigenous macrophytes (i.e. Nuphar lutea, Mentha aquatica, Typha latifolia, Glyceria aquatica, Ceratophyllum demersum, Phalaris arundinacea) and contained no fish.

Table 1. Ingredient composition and characteristics of the feed supplied.

\begin{tabular}{ll}
\hline Ingredient (\%) & \\
\hline Wheat middlings & 31.0 \\
Soybean meal & 27.0 \\
Rapeseed meal & 18.0 \\
Fish meal & 8.0 \\
Fish oil & 5.0 \\
Lactoserum & 3.0 \\
Extruded peas & 3.0 \\
Vitamin premix & 2.5 \\
Monocalcium phosphate & 2.5 \\
\hline Nutrient content $(\%)$ & \\
\hline Dry matter & 89.44 \\
Crude protein & 31.10 \\
Fat & 8.28 \\
Crude fiber & 6.88 \\
Ash & 7.81 \\
Total nitrogen & 1 \\
Total phosphorus & 4.98 \\
\hline
\end{tabular}

${ }^{1}$ Calculated by dividing the crude protein value by 6.25 .

\subsection{Fish assemblage}

Three fish species were included in the polyculture: common carp (C. carpio), roach (Rutilus rutilus) and tench (Tinca tinca). Common carp was chosen for its market value and was the target species of the system. Its sediment-stirring activity induces pond bioturbation that helps to cycle nutrients. Roach was chosen for its ability to reproduce easily, producing a large number of fry that eat phytoplankton and zooplankton. These fry are potential prey of carp, tench and macroinvertebrates. Carp and roach have a similar trophic level (3.1 and 3.0, respectively) (Fishbase, Christensen and Pauly, 1992) and are omnivorous; they eat benthic organisms and plants (and, for roach, zooplankton). Tench are considered carnivorous (trophic level 3.7) but they also eat detritus and plant materials.

A total of 1500 common carp were randomly divided among the six ponds. Carp density in extensive ponds (150 $\mathrm{carp} /$ pond $\left.=3000 \mathrm{carp} \cdot \mathrm{ha}^{-1}=417 \mathrm{~kg} \cdot \mathrm{ha}^{-1}\right)$ was half that in fed fishponds $\left(300 \mathrm{carp} /\right.$ pond $=6000 \mathrm{carp} \cdot \mathrm{ha}^{-1}=$ $834 \mathrm{~kg} \cdot \mathrm{ha}^{-1}$ ) to ensure that fish density did not exceed available resources (Tab. 2). For the other species, each pond was stocked with 42 roach $\left(840 \mathrm{roach} \cdot \mathrm{ha}^{-1}=58 \mathrm{~kg} \cdot \mathrm{ha}^{-1}\right)$ and 23 tench (460 tench $\left.\cdot \mathrm{ha}^{-1}=1.5 \mathrm{~kg} \cdot \mathrm{ha}^{-1}\right)($ Tab. 2$)$.

\subsection{Monitoring and measurements}

\subsubsection{Fish monitoring}

Several system characteristics were measured to understand the mechanisms involved in pond ecological intensification. Fish growth performances were recorded to assess the

Table 2. Harvest and survival rate results.

\begin{tabular}{|c|c|c|c|c|c|c|c|}
\hline Indicator & $\begin{array}{l}\text { Treatment } \\
\text { replicate }\end{array}$ & \multicolumn{2}{|c|}{ Extensive } & \multicolumn{2}{|c|}{ Semi-intensive } & \multicolumn{2}{|c|}{ Coupled } \\
\hline \multirow[t]{3}{*}{ Number of fish stocked } & Carp adult & 150 & 150 & 300 & 300 & 300 & 300 \\
\hline & Roach adult & 42 & 42 & 42 & 42 & 42 & 42 \\
\hline & Tench adult & 23 & 23 & 23 & 23 & 23 & 23 \\
\hline Mean weight at stocking $(\mathrm{g})$ & Carp adult & 136 & 140 & 141 & 136 & 138 & 142 \\
\hline \multirow[t]{6}{*}{ Number of fish harvested } & Carp adult & 140 & 128 & 287 & 292 & 276 & 272 \\
\hline & Roach adult & 37 & 23 & 38 & 34 & 1 & 4 \\
\hline & Tench adult & 10 & 10 & 21 & 23 & 18 & 22 \\
\hline & Carp fry & 0 & 44 & 100 & 34 & 88 & 0 \\
\hline & $\mathrm{S} 1^{1}$ roach fry & 934 & 121 & 996 & 461 & 219 & 607 \\
\hline & $\mathrm{S} 2^{1}$ roach fry & 199 & 4386 & 274 & 679 & 79 & 8 \\
\hline Survival rates $(\%)$ & Tench adult & 43.4 & 43.4 & 91.3 & 100.0 & 78.3 & 95.7 \\
\hline \multirow[t]{6}{*}{ Mean weight at harvest ( $\mathrm{g}$ ) } & Carp adult & 195 & 196 & 668 & 637 & 621 & 608 \\
\hline & Roach adult & 75 & 57 & 106 & 98 & 93 & 71 \\
\hline & Tench adult & 35 & 26 & 70 & 62 & 30 & 42 \\
\hline & Carp fry & - & 12.1 & 11.5 & 8.3 & 54.8 & - \\
\hline & $\mathrm{S} 1^{1}$ roach fry & 3.3 & 3.2 & 3.1 & 4.6 & 3.1 & 5.7 \\
\hline & $\mathrm{S} 2^{1}$ roach fry & 1.4 & 1.4 & 1.3 & 2.0 & 0.8 & 2.6 \\
\hline
\end{tabular}

\footnotetext{
${ }^{1} \mathrm{~S} 1$ indicates the first spawning period and S2 indicates the second spawning period.
} 
influence of formulated feed on fish production. At the beginning of the experiment, a sample of 60 roach and 150 carp were individually weighed and sized. The remaining carp, roach and tench were weighed in groups to estimate the total biomass of each species in each pond. Formulated feed was supplied once a day at the rate of $2 \%$ of fish live weight, and adjusted according to water temperature (Tab. I, Supplementary data). The amount of feed supplied was weighed and recorded daily. At the end of the experiment, fish in each pond were harvested, counted and sorted by species and size class. A sample of fish from each pond was individually weighed and sized, and the remaining fish were weighed in groups of similar size. Because roach can spawn several times during the breeding season, roach fry were sorted by weight. Assuming that roach had spawned twice, we attributed roach fry less than $2 \mathrm{~g}$ to the second spawn (S2) and those greater than $2 \mathrm{~g}$ to the first spawn (S1). Survival rate, Fulton's condition factor (K) (Froese, 2006), specific growth rate (SGR) and feed conversion ratio (FCR) were calculated as follows:

$$
\text { Survival rate }(\%)=\left(\frac{N h}{N s}\right) \times 100
$$

where $N s$ is the number of fish of a given species at stocking, and $N h$ is the number of adults of the same species at harvest.

$$
K i=\left(\frac{W i}{L i^{3}}\right) \times 100
$$

where $W i$ is individual live weight $(\mathrm{g})$, and $L i$ is individual length at the caudal fork $(\mathrm{cm})$.

$$
K=\sum K i / n
$$

where $K i$ is the individual Fulton's condition factor of fish of a given species and $n$ the number of individually measured fish of the same species.

$$
\operatorname{SGR}\left(\% \cdot \text { day }^{-1}\right)=\left(\frac{\ln (W h)-\ln (W s)}{\text { time }(\text { days })}\right) \times 100
$$

where $W h$ and $W s$ are the mean weight at harvest and stocking, respectively.

$$
\operatorname{FCR}\left(\mathrm{kg} \cdot \mathrm{kg}^{-1}\right)=\left(\frac{\text { food intake }(\mathrm{kgDM})}{\text { fish net weight gain }(\mathrm{kg})}\right),
$$

where FCR was calculated for each pond, and we assumed that only carp consumed the formulated feed, even though other species may have done so. To determine nutrient retention efficiency and the fate of nutrients in each treatment, the mass balance of $\mathrm{N}$ and phosphorus $(\mathrm{P})$ compounds was calculated by considering the input and output of each pond. $\mathrm{N}$ and $\mathrm{P}$ in fish were estimated from data on $\mathrm{N}$ and $\mathrm{P}$ contents available for roach (Schreckenbach et al., 2001; Dantas and Attayde, 2007; Boros et al., 2012), carp and tench (Schreckenbach et al., 2001). $N$ and $P$ in water and sediments were obtained from water quality monitoring (described below). The volumes of water used were estimated by monitoring the depth of each pond. Mass balance was calculated for each nutrient ( $\mathrm{N}$ or $\mathrm{P}$ ) and for each pond as follows:

$$
\text { nutrient retention }=(F+B b+W f)-(B e+W d),
$$

where $F, B b, B e, \mathrm{~W} f$ and $W d$ are the quantity of nutrients in the formulated feed supplied, fish biomass at stocking, fish biomass at harvest, fill water and drained water, respectively.

\subsubsection{Water quality monitoring and sediment composition}

Water quality was assessed mainly through physical parameters: temperature, $\mathrm{pH}$, dissolved oxygen (DO), oxygen saturation $\left(\% \mathrm{O}_{2}\right)$, conductivity, redox potential, transparency and nutrient concentrations ( $\mathrm{N}$ and $\mathrm{P})$ in water and sediments. A biological parameter (i.e. chlorophyll concentration) was also assessed. Once a month, from March to November, water was sampled from each pond for temperature (multiparameter Templight Hobo Data Loggers, 64K UA-002-64, Onset Co.), pH (WTW 340i, Sentix Plus 41 probe), DO and $\% \mathrm{O}_{2}(\mathrm{HACH}$ HQ30, LDO probe), conductivity (WTW 340i, Tetracon 325 probe) and transparency (Secchi disk). To limit effects of daily variation in sunlight on biotic and abiotic parameters, water was sampled each day at $3 \mathrm{pm} \pm 1 \mathrm{~h}$.

One water sample from each pond was collected at the beginning of the experiment, and once a month until harvest, except in September. River water was also sampled each time it was added to the pond to compensate for evaporation and seepage. In September, each pond was monitored for $24 \mathrm{~h}$. One water sample was automatically collected every $2 \mathrm{~h}$ (ISCO 3700 water sampler). At the same time, temperature, $\mathrm{pH}, \mathrm{DO}$, $\% \mathrm{O}_{2}$, conductivity and redox potential were automatically monitored at a depth of $50 \mathrm{~cm}$ and logged every $5 \mathrm{~min}$ (5 Hydrolab multi-analyzer probe). Each pond was drained in one-third increments at the end of the rearing period. Water was sampled at the exit of the discharge pipe at each increment. Several drops of sulfuric acid $(25 \mathrm{~N})$ were immediately added to each water sample collected during the experiment to stop bacterial activity, and samples were then stored at $3{ }^{\circ} \mathrm{C}$. Samples were analyzed to measure concentrations of phosphate $\left(\mathrm{PO}_{4}{ }^{3-}\right)$ and total $\mathrm{P}$ (TP) (ISO 6878:2004), ammonia $\left(\mathrm{NH}_{4}{ }^{+}\right)$(ISO 11372:1997), nitrite $\left(\mathrm{NO}_{2}{ }^{-}\right)$and nitrate $\mathrm{N}\left(\mathrm{NO}_{2}{ }^{-}+\mathrm{NO}_{3}{ }^{-}\right)$(ISO 13395:1996) and total $\mathrm{N}(\mathrm{TN})$ (ISO 11905-1:1997).

From March to June, chlorophyll- $a$ concentrations in each pond were measured (AFNOR standard NF T90-117) once a month with a spectrophotometer (Analytik Jena SPECORD 205S/TBIO). From late July to November, chlorophyll concentrations in blue algae (Cyanophyceae), green algae (Chlorophyceae, Tebrouxiophyceae and Zygophyceae), brown algae (Dinophyceae and Bacillariophyta) and total algae were measured once a month with a fluorometer phytoplankton analyzer (PHYTO-PAM, WALZ Co., Germany).

Sediment samples were collected from pond bottoms by pushing a 6-cm diameter core tube down to the gravel bottom of each pond. Sediment composition was assumed to be homogenous in each pond at the beginning of the experiment. Consequently, samples were collected at a single central point at the beginning of the experiment and at three points (shallow end, central point and deep end) at harvest. Samples were dried at $50{ }^{\circ} \mathrm{C}$ to a constant weight (nearly $48 \mathrm{~h}$ ) to calculate dry 
Table 3. Means of biometric indicators calculated from individual measurements for each treatment.

\begin{tabular}{|c|c|c|c|c|c|c|c|c|c|}
\hline \multirow[b]{2}{*}{ Indicator } & & \multicolumn{2}{|c|}{ Extensive } & \multicolumn{2}{|c|}{ Semi-intensive } & \multicolumn{2}{|c|}{ Coupled } & \multirow[b]{2}{*}{$\mathrm{RSE}^{2}$} & \multirow[b]{2}{*}{ Significance $^{3}$} \\
\hline & & Mean & $N^{1}$ & Mean & $N^{1}$ & Mean & $N^{1}$ & & \\
\hline Weight at stocking (g) & Carp adult & 128 & 50 & 130 & 50 & 114 & 50 & 45 & NS \\
\hline \multirow[t]{2}{*}{$K^{4}$ at fish stocking } & Carp adult & 2.72 & 50 & 2.61 & 50 & 2.57 & 50 & 0.42 & NS \\
\hline & Roach adult & 1.78 & 21 & 1.69 & 20 & 1.65 & 20 & 0.16 & NS \\
\hline \multirow[t]{5}{*}{ Weight at harvest (g) } & Carp adult & $199^{\mathrm{b}}$ & 215 & $655^{\mathrm{a}}$ & 168 & $616^{\mathrm{a}}$ & 188 & 185 & $* *$ \\
\hline & Tench adult & $30^{\mathrm{a}}$ & 20 & $67^{\mathrm{b}}$ & 38 & $42^{\mathrm{a}}$ & 22 & 19 & $* *$ \\
\hline & Carp fry & $11.2^{\mathrm{a}}$ & 42 & $8.9^{\mathrm{a}}$ & 33 & 57.4 & 49 & 27.9 & $* *$ \\
\hline & $\mathrm{S} 1^{5}$ roach fry & $3.3^{\mathrm{a}}$ & 76 & $4.1^{\mathrm{a}}$ & 92 & $6.6^{\mathrm{b}}$ & 264 & 2.7 & $* *$ \\
\hline & $\mathrm{S} 2^{5}$ roach fry & $1.3^{\mathrm{a}}$ & 64 & $1.6^{\mathrm{a}}$ & 140 & $1.0^{\mathrm{b}}$ & 75 & 0.7 & $* *$ \\
\hline \multirow[t]{2}{*}{$K^{4}$ at harvest } & Carp adult & $2.73^{\mathrm{a}}$ & 215 & $2.87^{\mathrm{ab}}$ & 168 & $3.22^{\mathrm{b}}$ & 188 & 2.03 & $*$ \\
\hline & Roach adult & $1.38^{\mathrm{b}}$ & 61 & $1.66^{\mathrm{a}}$ & 51 & $1.66^{\mathrm{a}}$ & 5 & 0.20 & $* *$ \\
\hline
\end{tabular}

\footnotetext{
${ }^{1}$ Number of individuals sampled to calculate values.

2 Residual standard error.

${ }^{3}$ Significance levels: ${ }^{* *} P<0.01,{ }^{*} P<0.05$. Same letters in each column indicate no significant differences at the $P<0.05$ level.

${ }^{4} K$ corresponds to the Fulton's condition factor and is calculated as $K=\left(\frac{W i}{L i^{5}}\right) \times 100$, where $W_{\mathrm{i}}$ is individual live weight (g), and $L_{\mathrm{i}}$ is individual length at the caudal fork $(\mathrm{cm})$.

${ }^{5} \mathrm{~S} 1$ indicates the first spawning period and S2 indicates the second spawning period.
}

matter (DM) and then analyzed for TP and TN (ISO 6878:2004 and ISO 10694:1995, respectively).

\subsubsection{Data analysis}

Individual fish biometry was performed at the beginning and end of the experiment on representative samples of each fish population of each pond and within treatments. Statistical analyses were performed on live weight and $\mathrm{K}$ using ANOVA (type III test of $\mathrm{R}$ software) to detect differences in performance among treatments for each fish species. The Kruskal-Wallis nonparametric test was used to detect differences between treatments, for the entire duration of the experiment, in water temperature, $\mathrm{pH}, \mathrm{DO}, \% \mathrm{O}_{2}$, conductivity, transparency, TN, TP, chlorophyll- $a$, total chlorophyll and percentage of blue, green and brown chlorophyll. If differences were detected, a Wilcox test was used to compare pairs of treatments. All the raw data are available in open access (Jaeger and Aubin, 2018).

\section{Results}

\subsection{Fish performances}

Fish were harvested from 26 to 28 November 2014. Fish numbers, survival rate and mean weight are detailed in Table 2. A few large carp were harvested from planted lagoons because the pipe net had been removed accidentally for at least one day. Therefore, we merged the harvest data of the coupled ponds. In addition to fish, red swamp crayfish (Procambarus clarkii) and tadpoles (Rana esculenta) were harvested from the two planted lagoons and extensive pond 1. Carp and roach fry were harvested, but no tench fry were harvested. The total number of fish at harvest varied greatly among ponds and treatments (681-4712 fish) (Tab. 2). Although adult carp survival rate was similar among ponds (85-97\%), it varied greatly for adult roach and tench. Survival rate was extremely low $(<10 \%)$ in the coupled treatment for adult roach and low $(<50 \%)$ in the extensive treatment for adult tench.

Indicators based on individual measurements are provided in Table 3, and total biomass is provided in Figure 2. Growth performances and feed efficiency are provided in Table I of the Supplementary data. At stocking, there were no significant differences in mean weight or mean $\mathrm{K}$ between fish of the same species between treatments. At harvest, for adults, mean weights of carp and roach from semi-intensive and coupled treatments $(655$ and $616 \mathrm{~g}$, respectively, for carp and 99 and $75 \mathrm{~g}$, respectively, for roach) were significantly higher $(p<0.01)$ than those in the extensive treatment $(199$ and $68 \mathrm{~g}$, respectively) (Tab. 3). In the extensive treatment, fish fry represented $10-20 \%$ of total fish biomass and $33-72 \%$ of total fish net weight gain at harvest. In the semi-intensive and coupled treatments, fish fry biomass was similar, but represented a lower percentage of fish biomass (1.9-3.1\%) and fish net weight gain $(2.5-4.2 \%)$ at harvest due to larger adult fish populations. The biomass of tadpoles and crayfish was negligible $(<0.2 \%$ total biomass $)$ for two of the three ponds from which they were harvested but reached $1.2 \%$ of total biomass in coupled pond 1. FCR of the carp population was higher in the coupled treatment $(2.12-2.24)$ than in the semi-intensive treatment (1.85-1.90). At stocking, $\mathrm{K}$ was 


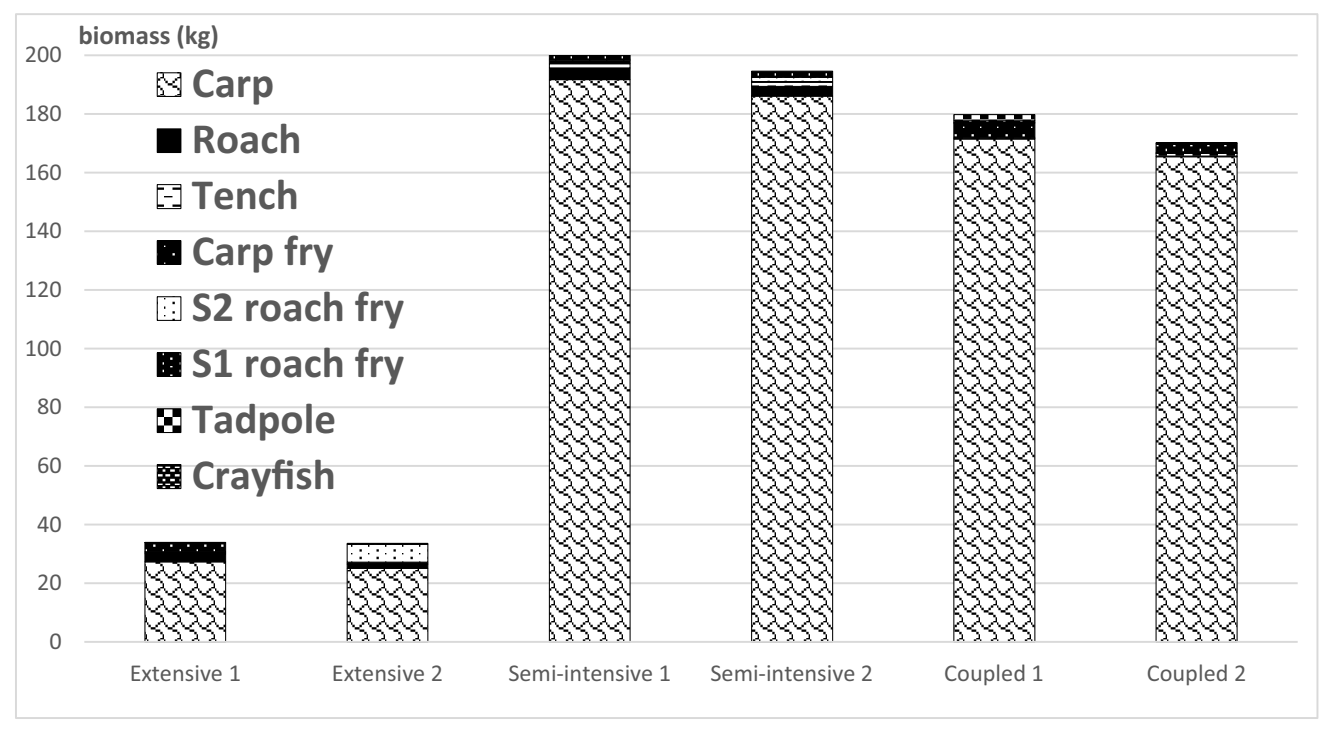

Fig. 2. Cumulative animal biomass harvested at the end of the experiment in carp polyculture ponds: extensive (without formulated feed), semiintensive (with feed and double fish density) and coupled (semi-intensive + planted lagoon).

Table 4. Means of chemical, physical and biological indicators of the water in ponds for each treatment during the experiment.

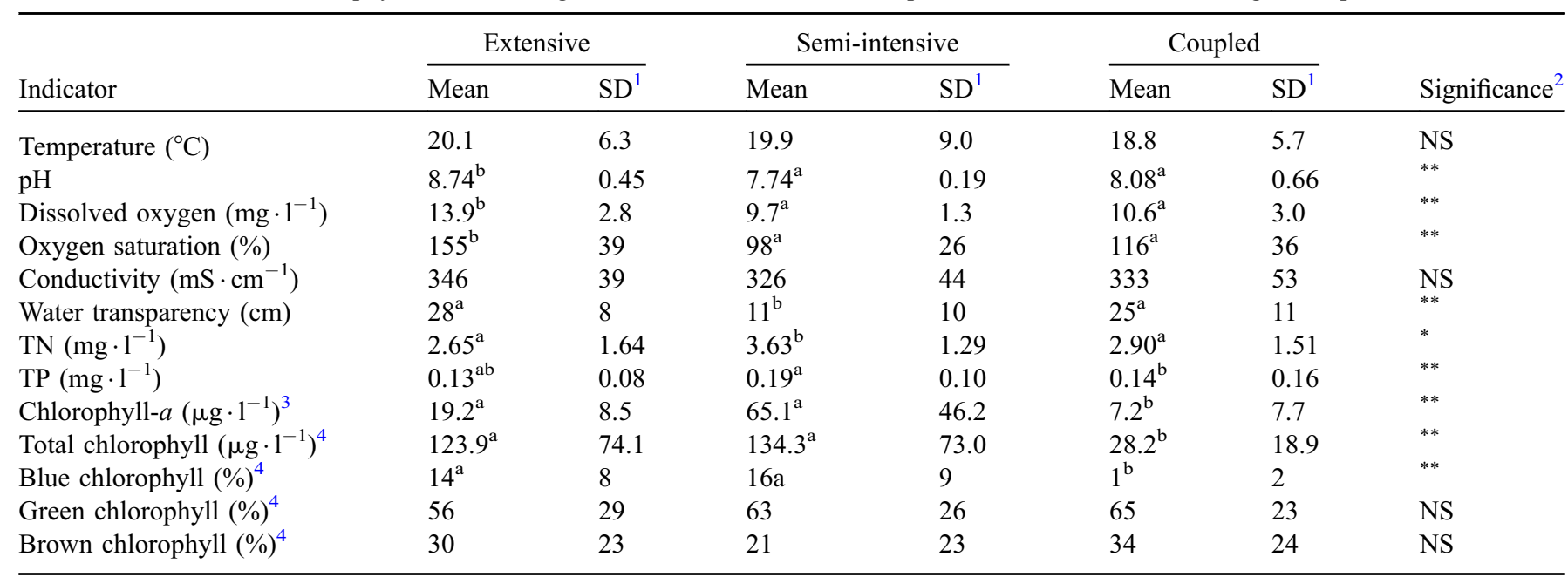

\footnotetext{
${ }^{1}$ Standard deviation.

${ }^{2}$ Significance levels: ${ }^{*} P<0.01,{ }^{*} P<0.05$. Same letters in each column indicate no significant differences at the $P<0.05$ level.

${ }^{3}$ From March to June.

${ }^{4}$ From July to November.
}

similar among treatments for carp (2.57-2.72) and roach (1.65-1.78). At harvest, $\mathrm{K}$ of adult carp in the coupled treatment (3.22) was significantly higher $(p<0.05)$ than that in the extensive treatment (2.73), but that in the semi-intensive treatment (2.87) did not differ significantly from the other two. $\mathrm{K}$ of roach in the extensive treatment (1.38) was significantly lower $(p<0.01)$ than those in the two other treatments $(1.66)$. K of tench did not differ significantly among treatments.

\subsection{Water quality}

Among all ponds, mean water temperature during the rearing period was $19.4{ }^{\circ} \mathrm{C}$, ranging from a mean of $10.7^{\circ} \mathrm{C}$ in
November to a mean of $27.5^{\circ} \mathrm{C}$ in July (Fig. I, Supplementary data), but no significant difference was observed between treatments (Tab. 4). Water $\mathrm{pH}$ varied greatly among treatments (Fig. 3). For the entire duration of the experiment, mean $\mathrm{pH}$ was significantly lower $(p<0.01)$ in semi-intensive and coupled treatments $(7.7 \pm 0.2$ and $8.1 \pm 0.7$, respectively) than that in the extensive treatment $(8.7 \pm 0.5)$. Oxygen saturation (Fig. 4) varied among treatments in a pattern similar to that of $\mathrm{pH}$ : mean $\% \mathrm{O}_{2}$ in the extensive treatment $(155 \pm 39 \%)$ was significantly higher $(p<0.01)$ than those in the semi-intensive and coupled treatments $(98 \pm 26 \%$ and $116 \pm 36 \%$, respectively) (Tab. 4). All ponds had similar conductivity dynamics, with a constant value from March to June (at a mean of 


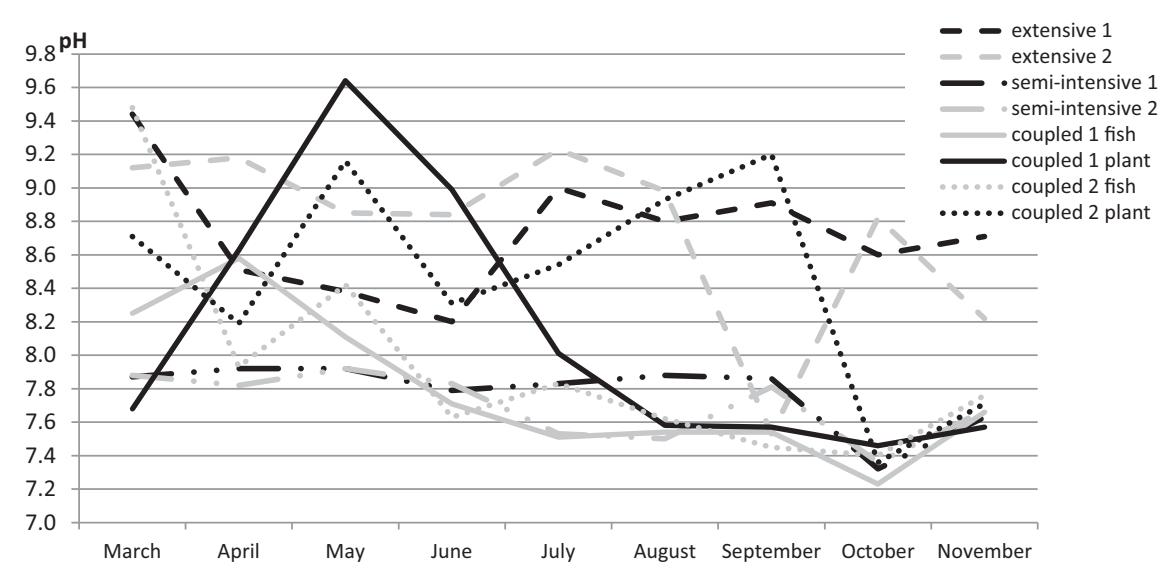

Fig. 3. Water $\mathrm{pH}$ dynamics during the rearing period in two replicates of carp polyculture ponds: extensive (without formulated feed), semiintensive (with feed and double fish density) and coupled (semi-intensive (fish) + planted lagoon (plant)).

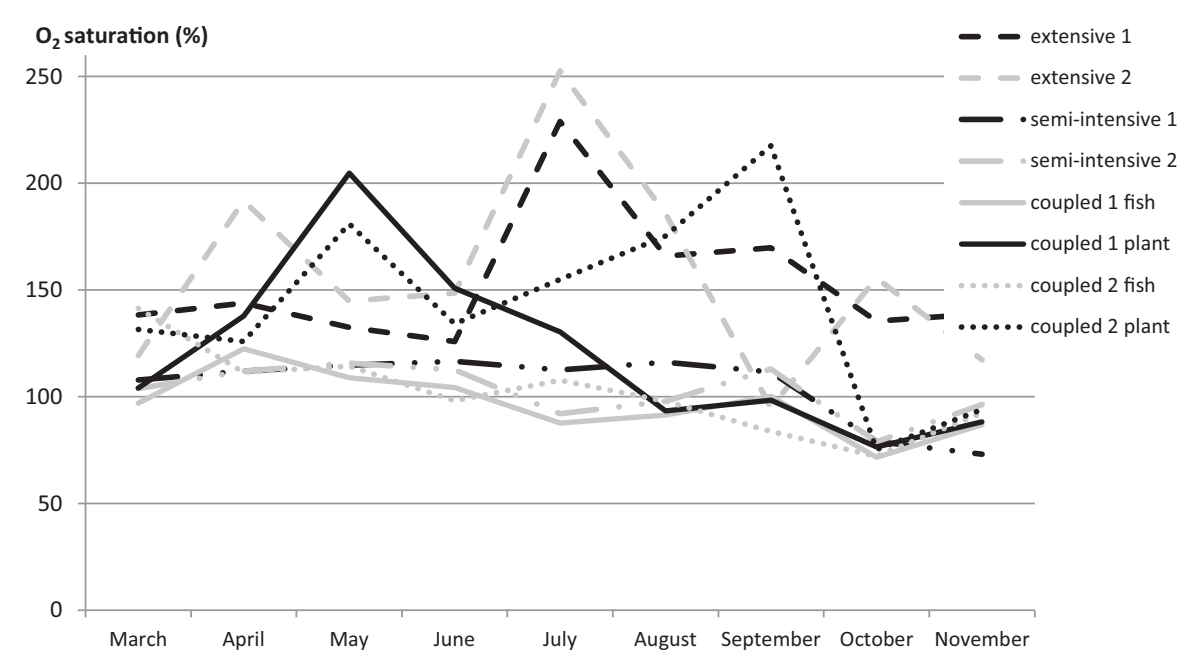

Fig. 4. Water oxygen saturation dynamics during the rearing period in two replicates of carp polyculture ponds: extensive (without formulated feed), semi-intensive (with feed and double fish density) and coupled (semi-intensive (fish) + planted lagoon (plant)).

$289 \mathrm{mS} \cdot \mathrm{cm}^{-1}$ ) and a strong increase in July, which plateaued (to a mean of $371 \mathrm{mS} \cdot \mathrm{cm}^{-1}$ ) until the end of the experiment (Fig. II, Supplementary data). For the entire duration of the experiment, no significant difference in mean conductivity was observed between treatments, but mean water transparency (Fig. III, Supplementary data) was significantly lower $(p<0.01)$ in the semi-intensive treatment $(11 \pm 10 \mathrm{~cm})$ than those in the extensive and coupled treatments $(28 \pm 8 \mathrm{~cm}$ and $25 \pm 11 \mathrm{~cm}$, respectively) (Tab. 4). TN concentration among all treatments decreased from March to May (from a mean of $5.16 \mathrm{mg} \cdot 1^{-1}$ to $1.49 \mathrm{mg} \cdot 1^{-1}$ ) and remained low until June, when it began to increase, plateauing at a mean of $2.64 \mathrm{mg} \cdot 1^{-1}$ in coupled and extensive ponds and $4.06 \mathrm{mg} \cdot 1^{-1}$ in semiintensive ponds (Fig. 5). For the entire duration of the experiment, mean TN was significantly higher $(p<0.05)$ in the semi-intensive treatment $\left(3.63 \pm 1.29 \mathrm{mg} \cdot \mathrm{l}^{-1}\right)$ than those in the extensive and coupled treatments $\left(2.65 \pm 1.64 \mathrm{mg} \cdot 1^{-1}\right.$ and $2.90 \pm 1.51 \mathrm{mg} \cdot 1^{-1}$, respectively) (Tab. 4). TP concentration remained relatively constant (a mean of $0.09 \mathrm{mg} \cdot 1^{-1}$ in each treatment until September, when it slowly increased until harvest to a mean of $0.16 \mathrm{mg} \cdot 1^{-1}$ in extensive and coupled treatments and $0.29 \mathrm{mg} \cdot 1^{-1}$ in semi-intensive ponds (Fig. 6). For the entire duration of the experiment, mean TP was significantly higher $(p<0.01)$ in the semi-intensive treatment $\left(0.19 \pm 0.10 \mathrm{mg} \cdot \mathrm{1}^{-1}\right)$ than that in the coupled treatment $\left(0.14 \mathrm{mg} \cdot 1^{-1} \pm 0.16 \mathrm{mg} \cdot \mathrm{l}^{-1}\right)$, but that in the extensive treatment did not differ significantly from those in the other two treatments (Tab. 4).

Water analyses during 24-h sampling indicated that, on the date of analysis, redox potential; conductivity; and concentrations of $\mathrm{PO}_{4}{ }^{3-}, \mathrm{NO}_{2}{ }^{-}+\mathrm{NO}_{3}{ }^{-}, \mathrm{NH}_{4}{ }^{+}, \mathrm{TN}$ and $\mathrm{TP}$ remained constant. $\mathrm{NO}_{2}{ }^{-}$concentrations remained too low to be detected in 24-h and monthly analyses (Tab. II, Supplementary data). Water temperature (Fig. IV, Supplementary data), DO (Fig. V, Supplementary data), $\% \mathrm{O}_{2}$ and $\mathrm{pH}$ had circadian dynamics, increasing during the day and decreasing at night.

\subsection{Chlorophyll}

Throughout the experiment, concentrations of chlorophyll- $a$ (Fig. 7) and total chlorophyll (Fig. 8) were sampled at the 


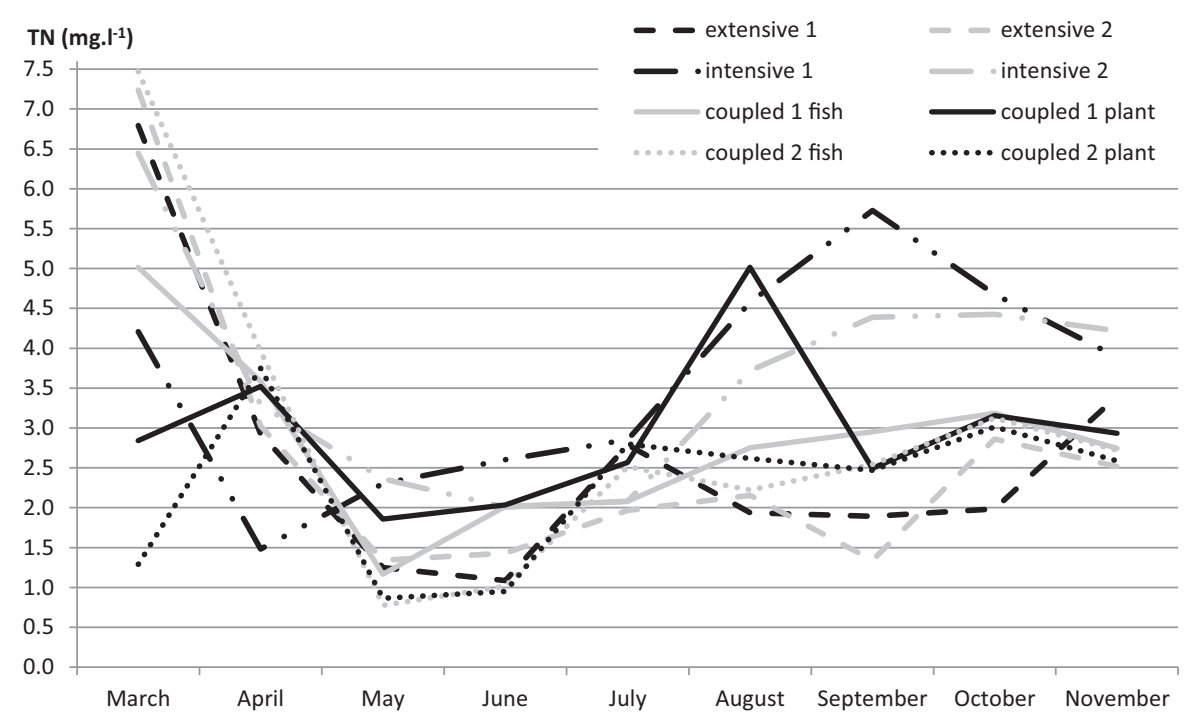

Fig. 5. Total nitrogen (TN) dynamics in the water during the rearing period in two replicates of carp polyculture ponds: extensive (without formulated feed), semi-intensive (with feed and double fish density) and coupled (semi-intensive (fish) + planted lagoon (plant)).

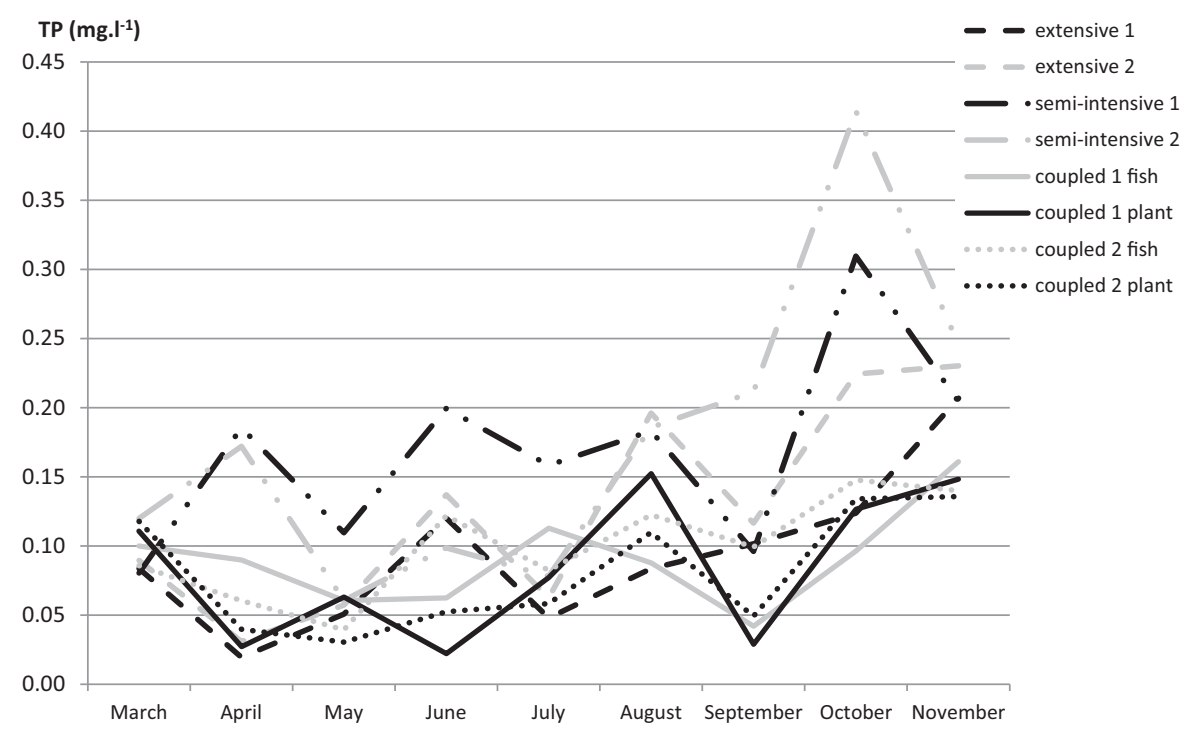

Fig. 6. Total phosphorus (TP) dynamics in the water TP during the rearing period in two replicates of carp polyculture ponds: extensive (without formulated feed), semi-intensive (with feed and double fish density) and coupled (semi-intensive (fish) + planted lagoon (plant)).

same moment of the day. Concentrations in the coupled treatment tended to remain in narrow ranges $(0.0-46.9$ and $7.1-66.4 \mu \mathrm{g} \cdot 1^{-1}$, respectively). In contrast, ranges of concentrations of chlorophyll- $a$ and total chlorophyll were broader in the semi-intensive treatment (6.4-124.0 and 58.8$268.1 \mu \mathrm{g} \cdot 1^{-1}$, respectively) and the extensive treatment (2.048.1 and $26.4-226.3 \mu \mathrm{g} \cdot 1^{-1}$, respectively). From March to June, the mean concentration of chlorophyll- $a$ was significantly lower $(p<0.01)$ in the coupled treatment $\left(7.2 \pm 7.7 \mu \mathrm{g} \cdot \mathrm{1}^{-1}\right)$ than those in the extensive $\left(19.2 \pm 8.5 \mu \mathrm{g} \cdot 1^{-1}\right)$ and semi-intensive $\left(65.1 \pm 46.2 \mu \mathrm{g} \cdot 1^{-1}\right)$ treatments. From July to November, the mean concentration of total chlorophyll was also significantly lower $(p<0.01)$ in the coupled treatment $\left(28.2 \pm 18.9 \mu \mathrm{g} \cdot 1^{-1}\right)$ than those in the extensive $\left(123.9 \pm 74.1 \mu \mathrm{g} \cdot 1^{-1}\right)$ and semiintensive $\left(134.3 \pm 73.0 \mu \mathrm{g} \cdot \mathrm{1}^{-1}\right)$ treatments. Analyzing the percentages of the three types of chlorophyll, a significant difference $(p<0.01)$ between treatments was detected only in the percentage of blue chlorophyll, which was significantly lower in the coupled treatment $(1 \pm 2 \%)$ than those in the extensive $(14 \pm 8 \%)$ and semi-intensive $(16 \pm 9 \%)$ treatments (Tab. 4).

\subsection{Sediments}

TN concentrations in pond sediments ranged from $2.20-4.21 \mathrm{mg} \cdot \mathrm{g}^{-1} \mathrm{DM}$ at stocking, and mean TN ranged from $2.48-4.79 \mathrm{mg} \cdot \mathrm{g}^{-1} \mathrm{DM}$ at harvest. TP concentrations in pond sediments ranged from $0.24-0.47 \mathrm{mg} \cdot \mathrm{g}^{-1} \mathrm{DM}$ at stocking, and mean TP ranged from $0.39-0.75 \mathrm{mg} \cdot \mathrm{g}^{-1} \mathrm{DM}$ at harvest (Tab. 5). TN and TP increased in all treatments. In 


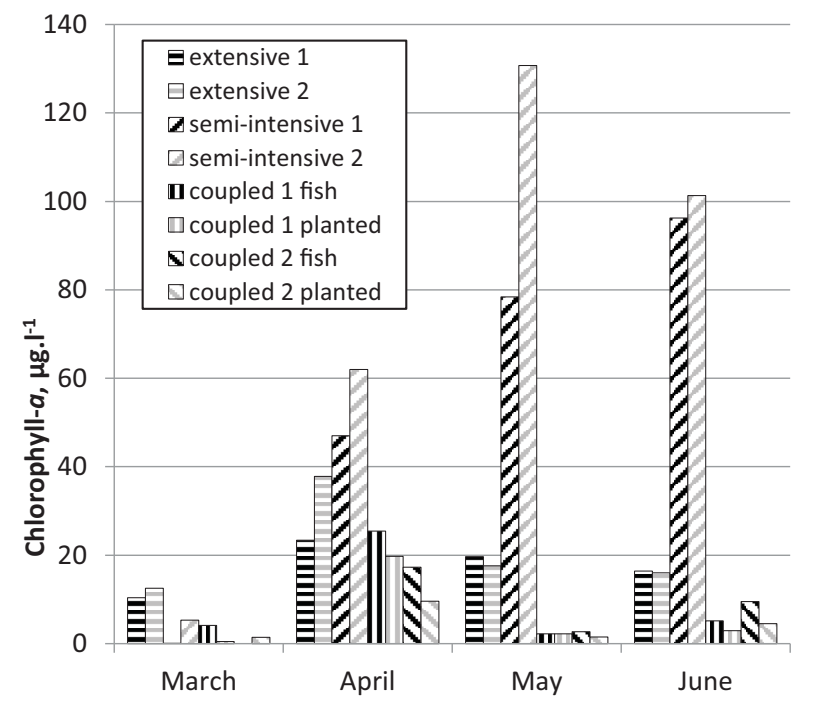

Fig. 7. Chlorophyll-a concentration in water from March to June 2014 in each pond.

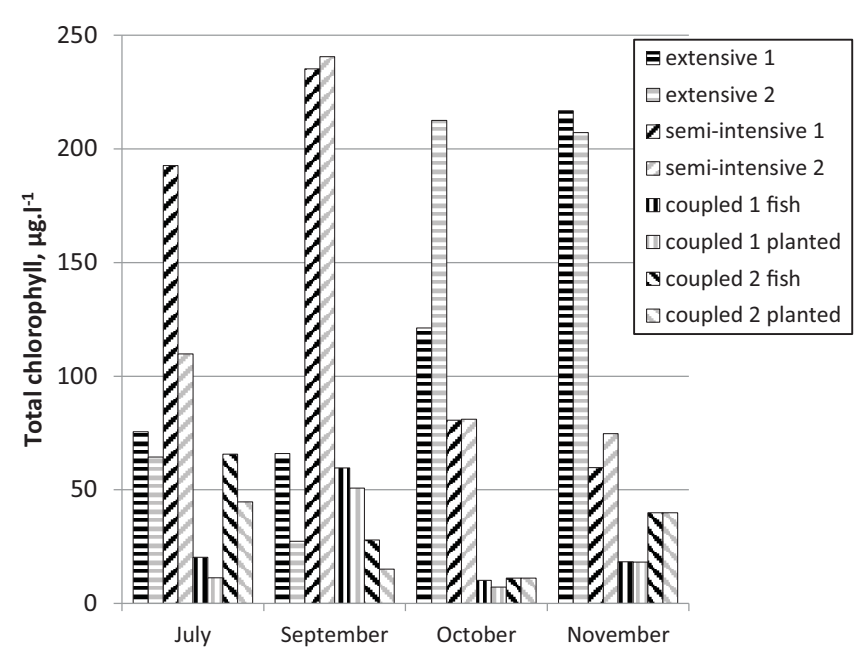

Fig. 8. Total chlorophyll concentrations in water from July to November 2014 in each pond.

Table 5. Total nitrogen (TN) and phosphorus (TP) contents in the sediment $\left(\mathrm{mg} \cdot \mathrm{g}^{-1}\right.$ dry sediment) of each pond at fish stocking and harvest.

\begin{tabular}{|c|c|c|c|c|c|c|}
\hline \multirow[b]{2}{*}{ Pond } & \multicolumn{3}{|c|}{$\mathrm{TN}$} & \multicolumn{3}{|c|}{$\mathrm{TP}$} \\
\hline & Stocking $^{1}$ & Harvest $^{2}$ & $\Delta^{3}$ & Stocking $^{1}$ & Harvest $^{2}$ & $\Delta^{3}$ \\
\hline Extensive 1 & 2.67 & 2.88 & 0.21 & 0.47 & 0.53 & 0.06 \\
\hline Extensive 2 & 2.83 & 3.38 & 0.55 & 0.45 & 0.54 & 0.09 \\
\hline Semi-intensive 1 & 4.21 & 4.79 & 0.58 & 0.39 & 0.75 & 0.36 \\
\hline Semi-intensive 2 & 2.20 & 2.58 & 0.38 & 0.24 & 0.39 & 0.15 \\
\hline Coupled 2 fish & 2.53 & 2.48 & -0.05 & 0.43 & 0.50 & 0.07 \\
\hline Coupled 2 plant & 3.09 & 3.35 & 0.26 & 0.42 & 0.56 & 0.14 \\
\hline
\end{tabular}

\footnotetext{
${ }^{1}$ Values obtained from analyzing a single sample collected at a single central point at the beginning of the experiment for each pond.

${ }^{2}$ Mean values from analyzing samples collected at three points (shallow end, central point and deep end) at harvest for each pond.

${ }^{3} \Delta$ is the change in concentration from fish stocking to harvest.
}

the coupled treatment, TP clearly increased more in planted lagoons than in fishponds, while TN decreased in fishponds but increased in planted lagoons.

\subsection{Mass balance of $\mathrm{N}$ and $\mathrm{P}$}

In the semi-intensive treatment, $\mathrm{N}$ in total fish net weight gain was $60-83 \%$ of $\mathrm{N}$ input (from fill water and formulated feed). $\mathrm{N}$ from feed was nearly $50 \%$ of the $\mathrm{N}$ in total fish net weight gain, indicating that the food web (in water, sediments, etc.) provided at least the other $50 \%$. In coupled fishponds, $\mathrm{N}$ in total fish net weight gain was $58-84 \%$ of $\mathrm{N}$ input. $\mathrm{N}$ from feed was $59 \%$ of the $\mathrm{N}$ in total fish net weight gain; thus, the food web provided at least $41 \%$. In the extensive treatment, $4-7 \%$ of $\mathrm{N}$ input and $32-83 \%$ of $\mathrm{P}$ input were retained in total fish net weight gain. In the semi-intensive treatment, $P$ in total fish net weight gain represented $143-156 \%$ of $P$ input. $P$ from feed was $55 \%$ of the $\mathrm{P}$ in total fish net weight gain; thus, the food web provided at least $45 \%$. In coupled fishponds, $\mathrm{P}$ in total fish net weight gain represented $134-135 \%$ of $P$ input. $P$ from feed was $69 \%$ of the $\mathrm{P}$ in total fish net weight gain; thus, the food web provided at least $31 \%$ (Tab. 6). When results of the two coupled ponds were merged, the percentage of nutrients retained in total fish net weight gain $(37-41 \%$ of $\mathrm{N}$ and $102-106 \%$ of $\mathrm{P}$ ) decreased, but remained greater than those in the extensive treatment. For all treatments, water drained at harvest had lower concentrations of $\mathrm{N}$ than that in the water supply, but the opposite was observed for P, except for extensive pond 2 .

\section{Discussion}

Fish reared in fed treatments had better growth performances and survival rates than those in the extensive treatment. Formulated feed seemed to increase the use of nutrients naturally available in the pond, which increased fish biomass. Fish in the extensive treatment seemed to retain the fewest nutrients, while those in the coupled treatment retained 


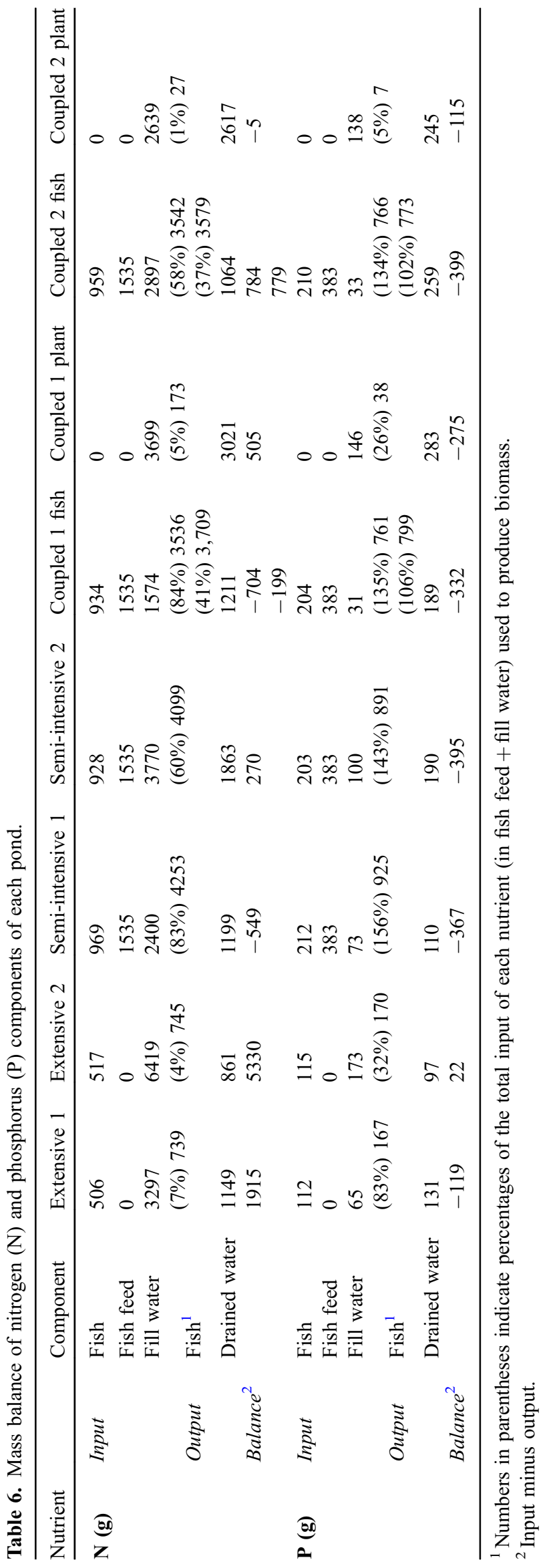

more, but not as much as those in the semi-intensive treatment. Survival rate tended to be high, except for roach in the coupled treatment, which may help explain why FCRs of fish in the coupled treatment were worse than that in the semiintensive treatment. Nevertheless, FCR was $15 \%$ higher in the semi-intensive treatment than in the coupled treatment, suggesting that planted lagoons may also have had an adverse effect on fish performances. Nevertheless, the final weight of individual carp in the coupled and semi-intensive treatments did not differ significantly.

The lower survival rate of roach in the coupled treatment may be explained by lower phytoplankton concentrations and thus zooplankton concentrations, which decreased prey for roach early in the experiment. The lower survival rate of tench in the extensive treatment than in other treatments suggests that the initial population of tench was too large for the resources available in the extensive treatment. Also in the extensive treatment, lower growth performances and $\mathrm{K}$ values for carp and roach seem to indicate that these species did not eat sufficiently. They may have been too large to feed effectively on phytoplankton and zooplankton in the water column (Rahman et al., 2010) or meiofaunal organisms in sediments (Weber and Traunspurger, 2015), unlike fry, which represented a large percentage of fish biomass at harvest. Indeed, the presence of fry indicated that introduced carp and roach adults spawned during the experiment, as expected. Quantities of fry biomass in fed treatments were similar to those in the extensive treatment, which supports the idea that adults and fry did not eat the same source of food. Priyadarshini et al. (2011) observed that growth performances of common carp fry reared in tanks supplied with manure or manure plus formulated feed did not differ significantly, whereas those of common carp fingerlings were significantly better when supplied with formulated feed (with or without manure) than when supplied only with manure. Thus, although fry growth performances can improve with natural food, those of larger fish require formulated feed to improve (Abbas et al., 2010). Given the goal of ecological intensification to produce one or more species for the economic market, it might be useful to adjust the fish assemblage in coupled pond systems. This could be done by rearing more smaller sized carp, which could eat both formulated feed and natural biomass in the pond, and by replacing tench with a carnivorous fish species of higher trophic level that eats prey such as fry, crayfish, tadpoles and macroinvertebrates.

Lower TN concentrations, lower water transparency and increased chlorophyll- $a$ and total chlorophyll concentrations in spring and summer indicate that, at least, $\mathrm{N}$ was used by phytoplankton to reproduce during warm periods, as described by Hargreaves (1998). However, unlike the two other treatments, no algae bloom was observed in the coupled treatment. This suggests that planted lagoons could directly or indirectly regulate algae growth and possibly the type of phytoplankton. Blue chlorophyll was observed mainly in the semi-intensive and the extensive treatments. Competition for nutrient use seems to favor macrophytes (Barbe et al., 2000). Thus, planted lagoons would have shifted primary production of the associated fishpond from phytoplankton to macrophytes, according to tipping points based on biotic indicators such as chlorophyll- $a$ concentration, which is associated with biodiversity of aquatic vascular macrophytes, dragonflies and 
macroinvertebrates (Vanacker et al., 2015), as well as with physico-chemical indicators such as water transparency, TN and TP (Vanacker et al., 2016). Low phytoplankton concentrations limited zooplankton development and possibly the growth of carp early in the experiment.

In agreement with Kerepeczki et al. (2003), the increase in $\mathrm{TN}$ concentration in water observed at the end of summer may correspond to a decrease in $\mathrm{N}$ removal efficiency, which also occurred for P. This is explained by the senescence and decomposition of aquatic vegetation (macrophytes and phytoplankton) (Vymazal, 2007) and the decrease in phytoplankton density (Hargreaves, 1998). To be more certain, observing the zooplankton population in each pond would help to assess phytoplankton dynamics (Didier, 2003; Ciric et al., 2015) and zooplankton's potential as food for fish.

The coupled treatment had lower mean concentrations in TN and TP than semi-intensive treatment, although coupled treatment produced nearly as much fish as semi-intensive treatment. Planted lagoons damped $\mathrm{pH}$ and $\mathrm{DO}$ variations observed over $24 \mathrm{~h}$. Vymazal (2007) observed that harvesting the aboveground biomass of emergent vegetation removed little $\mathrm{N}$ and $\mathrm{P}$, but doing so in systems lightly loaded in nutrients could remove relatively large amounts of $\mathrm{N}$ and $\mathrm{P}$ (100-200 $\mathrm{g} \mathrm{N} \mathrm{m}^{-2} \mathrm{yr}^{-1}$ and 10-20 $\left.\mathrm{g} \mathrm{P} \mathrm{m}^{-2} \mathrm{yr}^{-1}\right)$. Knosche et al. (2000) determined that carp ponds improve the quality of water released downstream and observed increased concentrations of $\mathrm{N}$ and $\mathrm{P}$ in sediments, in agreement with the present study. In coupled ponds, $\mathrm{N}$ was retained in the planted lagoons, $\mathrm{N}$ concentrations decreased in fishponds and more $\mathrm{P}$ was retained in lagoons than in fishponds. Thus, lagoons provide the greatest potential to stock $\mathrm{P}$ in the sediment. Nevertheless, while for all ponds, drainage water at harvest had lower $\mathrm{N}$ concentrations than the input water, the opposite was observed for $\mathrm{P}$. The mass balances calculated in the present study should have included the nutrients stored in sediments, which depend upon the amount of sediments in the pond. Unfortunately, sediment thickness varied greatly within each pond, making it difficult to estimate sediment volume and deposition rate. Gal et al. (2003) found that estimated $\mathrm{N}$ accumulation was lower than the $\mathrm{N}$ surplus calculated in the $\mathrm{N}$ balance. They estimated that $76 \%$ of the difference was lost to the atmosphere as $\mathrm{NH}_{3}$ or $\mathrm{N}_{2}$; however, gas emissions were not assessed in the present study. In return, $\mathrm{N}$ fixation in fishponds is a minor, but occasionally large, contributor to the $\mathrm{N}$ balance of aquaculture ponds supplied with formulated feeds (Hargreaves, 1998). Seepage also releases nutrients into the environment (Gross et al., 2000). Calculation of mass balance can be improved in the future by (i) accurately measuring the amount of sediment at stocking and harvest to quantify the amount of $\mathrm{N}$ and $\mathrm{P}$ it contains, (ii) separating upper and lower layers of sediment samples to estimate seepage losses, (iii) estimating production of plant biomass in planted lagoons and (iv) measuring emissions of gases such as $\mathrm{NH}_{3}$ and $\mathrm{N}_{2}$.

\section{Conclusion}

Our experiment improved understanding of the fate of nutrients in a complex system (i.e. IMTA). For a given initial fish density, treatments supplied with formulated feed clearly produced more fish biomass than extensive treatment. For a given amount of feed supplied, coupled treatment produced slightly less fish biomass than semi-intensive treatment. Macrophytes were not harvested, which precluded assessing economic benefits of combining fishponds with planted lagoons in the framework of ecological intensification. The coupled treatment had better water quality in spring and summer and seemed to have less variable nutrient dynamics and physico-chemical parameters $\left(\mathrm{pH}, \% \mathrm{O}_{2}\right)$ than the two other treatments. Even though the coupled treatment did not retain the $\mathrm{P}$ present in the water, lagoons provide the greatest potential to stock P in the sediment. Quantifying sediment stock is difficult, but it is an important step for improving assessments of ecological intensification in ponds. Thus, by developing coupled ponds that produce plants and fish, IMTA may be of interest as a form of ecological intensification. Future studies could focus on the production, harvest and sale of macrophytes with an economic value to improve environmental, biodiversity and economic performances of the system. Moreover, exploring the biodiversity of invertebrates (zooplankton and macro-invertebrates), especially in the benthos of the rearing ponds, could be an interesting topic for future research. Improving knowledge about how nutrients cycle from formulated feed to the multiple compartments of a pond would be useful to explore how nutrients pass through the food web, how to retain more nutrients in plant and fish biomass and the influence and contribution of formulated feed to food web compartments. To this end, it would be useful to study stable isotopes of carbon and $\mathrm{N}$ in the pond system.

\section{Supplementary Material}

Table I. Biomass at fish stocking and harvest, and growth performances.

Table II. Variation in water physico-chemical parameters in 24 hours recorded in September 2014.

Figure I. Water temperature dynamics during the rearing period in two replicates of carp polyculture ponds: extensive (without formulated feed), semi-intensive (with feed and double fish density), and coupled (semi-intensive (fish) + planted lagoon (plant)).

Figure II. Water conductivity dynamics during the rearing period in two replicates of carp polyculture ponds: extensive (without formulated feed), semi-intensive (with feed and double fish density), and coupled (semi-intensive (fish) + planted lagoon (plant)).

Figure III. Water transparency dynamics measured with a Secchi disk during the rearing period in two replicates of carp polyculture fishponds: extensive (without formulated feed), semi-intensive (with feed and double fish density), and coupled (semi-intensive (fish) + planted lagoon (plant))

Figure IV. Water temperature measured at a depth of $50 \mathrm{~cm}$ every 5 minutes for 24 hours in September 2014 in pond 2 of each treatment.

Figure V. Water Dissolved Oxygen (DO) measured at a depth of $50 \mathrm{~cm}$ every 5 minutes for 24 hours in September 2014 in pond 2 of each treatment.

The Supplementary Material is available at http://www.alrjournal.org/10.1051/alr/2018021/olm. 
Acknowledgments. The authors would like to acknowledge Antoine Gallard, Bernard Joseph, Yoann Bennevault, Caroline Gorzerino, Martine Ollitrault, Maïra Coke, Didier Azam, the entire team of the INRA-U3E experimental site and all the kind volunteers who helped to weigh and measure the fish. This experiment was financially supported by and benefited from feedback from the French National Research Agency project PISCEnLIT (ANR-09-STRA-08).

\section{References}

Abbas S, Ahmed I et al. 2010. Comparative effects of fertilization and supplementary feed on growth performance of three fish species. Int J Agric Biol 12: 276-280.

Aubin J, Rey-Valette $\mathrm{H}$ et al. 2014. Guide for implementing ecological intensification of aquaculture systems, INRA-Rennes.

Barbe J, Schlumberger O et al. 2000. Evaluation de la production piscicole potentielle des étangs. Ingénieries - EAT 22: 49-62.

Blancheton JP, Bosc P et al. 2009. The "new" European fish culture systems: recirculating systems, offshore cages, integrated systems. Cah Agric 18: 227-234.

Boros G, Jyvasjarvi $J$ et al. 2012. Between-lake variation in the elemental composition of roach (Rutilus rutilus L.). Aquat Ecol 46: 385-394.

Brune DE, Schwartz G et al. 2003. Intensification of pond aquaculture and high rate photosynthetic systems. Aquacult Eng 28: 65-86.

Christensen V, Pauly D. 1992. ECOPATH-II: a software for balancing steady-state ecosystem models and calculating network characteristics. Ecol Model 61: 169-185.

Ciric M, Subakov-Simic G et al. 2015. Effect of supplemental feed type on water quality, plankton and benthos availability and carp (Cyprinus carpio L.) growth in semi-intensive monoculture ponds. Aquacult Res 46: 777-788.

Crab R, Avnimelech Y et al. 2007. Nitrogen removal techniques in aquaculture for a sustainable production. Aquaculture 270: 1-14.

Dantas MC, Attayde JL. 2007. Nitrogen and phosphorus content of some temperate and tropical freshwater fishes. J Fish Biol 70: 100-108.

Didier S. 2003. Le plancton en étangs piscicoles extensifs: production et exportation. Hydrobiologie, Université de Metz, pp. 262.

Downing JA, Prairie YT et al. 2006. The global abundance and size distribution of lakes, ponds, and impoundments. Limnol Oceanogr 51: 2388-2397.

Fontaine P, Legendre M et al. 2009. Domestication of new species and sustainable development in fish culture. Cah Agric 18: 119-124.

Froese R. 2006. Cube law, condition factor and weight-length relationships: history, meta-analysis and recommendations. $J$ Appl Ichthyol 22: 241-253.

Gal D, Kerepeczki E et al. 2009. The waste nutrients reutilisation capacity of combined pond aquaculture systems. Analele Universitatii din Oradea, Fascicula: Ecotoxicologie, Zootehnie si Tehnologii de Industrie Alimentara, 307-316.

Gal D, Szabo P et al. 2003. Experiments on the nutrient removal and retention of a pond recirculation system. Hydrobiologia 506: $767-772$.
Gal D, Pekar F et al. 2007. Experiments on the operation of a combined aquaculture-algae system. Aquacult Int 15: 173-180.

Gal D, Pekar F et al. 2013. Potential of nutrient reutilisation in combined intensive-extensive pond systems. Aquacult Int 21: 927-937.

Gross A, Boyd CE et al. 2000. Nitrogen transformations and balance in channel catfish ponds. Aquacult Eng 24: 1-14.

Hargreaves JA. 1998. Nitrogen biogeochemistry of aquaculture ponds. Aquaculture 166: 181-212.

Hargreaves JA. 2006. Photosynthetic suspended-growth systems in aquaculture. Aquacult Eng 34: 344-363.

Jaeger C, Aubin J. 2018. Biological and physico-chemical dataset from different fishponds systems related to IMTA: fish, water and sediment. SEANOE. DOI: 10.17882/56675

Kerepeczki E, Gal D et al. 2003. Preliminary investigations on the nutrient removal efficiency of a wetland-type ecosystem. Hydrobiologia 506: 665-670.

Knosche R, Schreckenbach K et al. 2000. Balances of phosphorus and nitrogen in carp ponds. Fish Manage Ecol 7: 15-22.

Milstein A. 1992. Ecological aspects of fish species interactions in polyculture ponds. Hydrobiologia 231: 177-186.

Neori A, Chopin T et al. 2004. Integrated aquaculture: rationale, evolution and state of the art emphasizing seaweed biofiltration in modem mariculture. Aquaculture 231: 361-391.

Priyadarshini M, Manissery JK et al. 2011. Influence of feed, manure and their combination on the growth of Cyprinus carpio (L.) fry and fingerlings. Turk J Fish Aquat Sci 11: 577-586.

Rahman MM, Jo Q et al. 2008. A comparative study of common carp (Cyprinus carpio L.) and calbasu (Labeo calbasu Hamilton) on bottom soil resuspension, water quality, nutrient accumulations, food intake and growth of fish in simulated rohu (Labeo rohita Hamilton) ponds. Aquaculture 285: 78-83.

Rahman MM, Kadowaki S et al. 2010. Common carp (Cyprinus carpio L.) alters its feeding niche in response to changing food resources: direct observations in simulated ponds. Ecol Res 25: 303-309.

Ritvo G, Kochba M et al. 2004. The effects of common carp bioturbation on fishpond bottom soil. Aquaculture 242: $345-356$.

Schreckenbach K, Knosche R et al. 2001. Nutrient and energy content of freshwater fishes. J Appl Ichthyol 17: 142-144.

Turcios AE, Papenbrock J. 2014. Sustainable treatment of aquaculture effluents: what can we learn from the past for the future? Sustainability 6: 836-856.

Vanacker M, Wezel A et al. 2015. Determining tipping points in aquatic ecosystems: the case of biodiversity and chlorophyll alpha relations in fish pond systems. Ecol Indic 52: 184-193.

Vanacker M, Wezel A et al. 2016. Determination of tipping points for aquatic plants and water quality parameters in fish pond systems: a multi-year approach. Ecol Indic 64: 39-48.

Vymazal J. 2007. Removal of nutrients in various types of constructed wetlands. Sci Total Environ 380: 48-65.

Weber S, Traunspurger W. 2015. The effects of predation by juvenile fish on the meiobenthic community structure in a natural pond. Freshw Biol 60: 2392-2409.

Cite this article as: Jaeger C, Aubin J. 2018. Ecological intensification in multi-trophic aquaculture ponds: an experimental approach. Aquat. Living Resour. 31: 36 